
Motrivivência v. 27,
n. 46
p. 35-52,
dezembro/2015

\title{
BELEZA E FEMINILIDADE: o corpo feminino nas páginas da revista Vida Capichaba (1925-1939)
}

\author{
Cecília Nunes da Silva ${ }^{1}$ \\ Felipe Quintão de Almeida ${ }^{2}$ \\ Ivan Marcelo Gomes ${ }^{3}$
}

\section{RESUMO}

Esse artigo ${ }^{4}$ investiga imagens do feminino presentes na revista Vida Capichaba, periódico de publicação quinzenal que circulou, no Estado do Espírito Santo, entre as décadas de 1920 e 1950. Diante da longevidade do periódico, optamos por concentrar nossos esforços analíticos nas décadas de 1920 e 1930, especificamente entre os anos de 1925 e 1939. Compreendendo que o periódico ilustrado registrou a história em uma linguagem de imagens, embasando-nos em Mauad (2005), tomamos as imagens para fins de análise, entendendo que elas integraram e compuseram a revista de modo tão importante quanto os textos que nela se publicaram. A construção da beleza e de um corpo magro e jovem se tornaram características da nova mulher capixaba, sendo essas algumas das imagens mais abordadas pelo periódico. A busca pela beleza coloca a existência feminina em destaque, mas, também, determina regras de comportamento corporal.

Palvras-chave: Corpo Feminino; Beleza; Periódico

1 Mestre em Educação Física. UFES, Vitória/Espírito Santo, Brasil. E-mail: ceciliaef@hotmail.com

2 Doutor em Educação. Professor da UFES, Vitória/Espírito Santo, Brasil. E-mail: fqalmeida@hotmail.com

3 Doutor em Ciências Humanas. Professor da UFES, Vitória/Espírito Santo, Brasil. E-mail: ivanmgomes@hotmail.com

4 O presente trabalho contou com apoio financeiro da CAPES para sua realização. 


\section{INTRODUÇÃO}

A construção da feminilidade tem estado diretamente ligada à noção de beleza. Quanto mais bonita uma mulher, mais feminina é considerada. Esta concepção não se ergueu com a mesma proporção ao homem, pois sua figura não se mede em função de beleza, prioritariamente, mas, devido à virilidade e masculinidade. Assim, podemos interpretar, na esteira de Lipovetsky (1997), que o parecer tem importância primeira na identidade feminina. Muitas imagens insistem em identificá-las como o "belo sexo". Esta definição, contudo, é uma construção moderna.

A emergência e a confirmação da ideia da mulher como centro da beleza surge com o Renascimento. "O reconhecimento explícito e teorizado da superioridade estética do feminino, glorificação hiperbólica dos seus atributos físicos e espirituais" (LIPOVETSKY, 1997, p. 109), permitiu colocar na sociedade a lógica do "belo sexo". Assim, para que a beleza feminina assumisse posição privilegiada, foi preciso um momento histórico em que a sensibilidade artística não estivesse sob o domínio absoluto da verdade e da vontade da Igreja. A Europa do Renascimento foi o lugar no qual a beleza encarnou o corpo feminino. Na busca de conciliar e aproximar o homem de Deus, o humanismo do Renascimento colocou na beleza feminina uma qualidade poderosa e vantajosa. ${ }^{5} \mathrm{~A}$ beleza se tornou um meio de aproximação com Deus. Na vontade de romper com o profano, a beleza feminina se tornou criação divina. A beleza exterior seria um modo de exprimir a beleza da alma, do interior (ECO, 2004).

Além do âmbito das artes e das letras, outra condição que permitiu valorizar a beleza feminina foi a divisão entre a classe burguesa e a classe trabalhadora. Tal condição comportou uma camada de mulheres isentas do trabalho, que deveria se apresentar para a sociedade de forma positiva. Esta condição de ócio possibilitou associar feminilidade à práticas de beleza. As muIheres das classes elitizadas poderiam delongar-se enfeitando-se e ornamentando-se, tornando-se mais bonitas e distraindo-se, ao longo do dia, com a aplicação de pinturas no rosto, penteados complicados e sofisticados, enfeites grandes, pesados e luxuosos, uso de espartilhos e saltos altos. Uma série de artifícios que demarcam um nível social superior. A beleza em si, a partir daí, não remete a mais nada senão a ela própria. $\mathrm{Na}$ modernidade, a estética do feminino passa a ser consagrada como superior, pois ela enobrece a mulher (LIPOVETSKY, 1997). Ao mesmo tempo, critérios gerais e detalhados sobre o que as mulheres devem fazer e apresentar para serem consideradas belas começam a ser minuciosamente determinados. Para isso, os processos de especialização, de racionalização, de aferição e medicalização se unem à cultura do "belo sexo" que integra, portanto, a lógica de normatização sistemática da sociedade moderna. Nos processos e práticas destinados a alcançá-la, há também os movimentos de sistematização dos papéis dos sexos, visto que ser feminina implicaria em ser

5 A imagem da mulher como ser perigoso e diabólico passou, por meio dos poetas e dos letrados, a ser uma figura angelical. Nesse sentido, a beleza da mulher não alcança apenas os patamares físicos, mas, também, passa pela composição de suas virtudes (DEL PRIORE, 2000). 
bela, enquanto a masculinidade segue relacionada à razão e à capacidade de decisão (LIPOVETSKY, 1997).

O valor simbólico da beleza e as possibilidades atingidas pelas mulheres graças a ela não podem ser interpretados apenas como negativos. A beleza do feminino permitiu à mulher o direito de ser vista, de ser tema de discussões e de ser notada socialmente:

A supremacia estética do feminino só se afirmou no contexto de um processo de redução da sua dissemelhança de essência. Para lá da recondução dos sinais de disjunção dos sexos, produziu-se um movimento de reabsorção da exterioridade perigosa do feminino e, ao mesmo tempo, uma integração das mulheres na ordem nobre da cultura humana. Assim sendo, a irrupção histórica do "belo sexo" deverá ser interpretada menos como uma nova figura da relegação do feminino do que como um dos primeiros marcos da dinâmica moderna que engendrou o reconhecimento da dignidade humana e social da mulher (LIPOVETSKY, 1997, p. 123).

O "belo sexo" aprende a admirar essa nova imagem de si mesma e a mulher não apenas se olha, como também é olhada pelos homens. "A mulher é mostrada como 'para ver', um espetáculo contemplado narcisicamente por ela mesma ou avidamente pelos homens" (LIPOVETSKY, 1997, p. 115).

Nessa dupla admiração da beleza feminina encaixam-se as imagens do periódico ilustrado Vida Capichaba. O periódico Vida Capichaba se destaca pela importância que teve no período de sua existência no Espírito Santo e por se caracterizar como a primeira revista de grande repercussão do Estado (80 ANOS DE..., 2003).
Tomando a revista como fonte, catalogamos todos os números existentes na Biblioteca Pública Estadual do Espírito Santo, que guarda o arquivo mais completo do periódico. A revista tinha cerca de 40 páginas por edição e circulou quinzenalmente até 1948, quando as publicações seguiram mensais. Os anos catalogados foram: 1925, 1926, 1927, 1928, 1929, 1930, 1931, 1932, 1933, 1934, 1935, 1936, 1937, 1938, 1939, 1940, 1941, 1942, 1943, 1944, 1946, 1947, 1948, 1949, 1950, 1951, 1952, 1953, 1954, 1955, 1956, 1957. Na década de 1920 só não foram registrados os dois primeiros anos do surgimento da revista (1923 e 1924); todos os anos das décadas de 30, 40 e 50 foram registrados, exceto o de 1945 . Os anos não catalogados (1923; 1924 e 1945) se justifica em função de sua inexistência no arquivo da biblioteca. Diante da longevidade da revista Vida Capichaba, optamos por um recorte temporal, que compreende as décadas de 1920 e 1930. O material efetivamente analisado corresponde a 328 números, publicados entre os anos de 1925 e 1939. Como explicitado acima, os dois primeiros anos da criação da revista não foram catalogados devido a sua ausência na Biblioteca Estadual, por essa razão ambos não compreendem os números analisados.

Os anos de 1920 foram, de acordo com Soares (2010), os que provocaram uma profunda transformação cultural no Brasil. Esse período coloca em movimento um novo estilo de vida e uma nova sensibilidade, ligados às transformações da vida urbana. Conforme Lipovetsky (1997), graças à imprensa, o "universo feminino" vai, a partir dos anos 1920, ganhando visibilidade por meio de desenhos e de fotos, pois cada vez mais as mulheres belas e elegantes são representadas. A década seguinte, ainda 
segundo Soares (2010), mantém muito dos hábitos mais livres e mais descontraídos que fizeram parte de uma nova sensibilidade urbana. Ao mesmo tempo, os anos finais do decênio de 1930 apontam para uma série de acontecimentos que influem na vida dos indivíduos e de toda a sociedade, quais sejam, a ascensão do Estado Novo no Brasil, em 1937, e o advento da Segunda Guerra Mundial, em 1939. Assim, nosso recorte temporal se encerra no ano de 1939.

O longo período de circulação da revista é uma indicação de sua importância na imprensa capixaba, num período em que a efemeridade dos periódicos ilustrados parece acompanhar boa parte das publicações nacionais (MARTINUZZO, 2005; MELO, 2008; SOARES, 2010). Para Rangel (2011), a Vida Capichaba tinha como um de seus objetivos dar visibilidade à participação feminina na revista. Não houve, à época, outro órgão da imprensa local que o fizesse com tanta frequência e dimensão. Esta é uma das razões pelas quais foi escolhida, seja pela representatividade de suas imagens, seja pela possibilidade de interpretação que oferecia do papel do feminino.

Como espaço e tempo de produção de ideias representativas do ser moderno é que a Vida Capichaba se apresentou ao público. Já em seu primeiro editorial, em 1923, há várias menções à mulher capixaba:

A Vida Capichaba ahí está. Não é ainda a revista que idealizamos. Do terceiro número em diante é que ela vestirá sua roupagem definitiva. [...] Não se justifica a falta de uma revista nesta Capital: que já é uma linda e encantadora cidade de muitos milhares de habitantes. Toda a cidade linda tem uma revista linda, que conta a sua história, que perpetua as suas emoções, que perfuma a sua galanteria, que exalta a sua elegância e que guarda num pequeno livro de horas, as ânsias subtis de sua vida sentimental. [...] O Espírito Santo é um Estado de bellas mulheres, de creaturas suavíssimas, para as quaes o espírito e a graça, a inteligência e a finura, são os mais caros requisitos de belleza moral. $\mathrm{E}$ onde ha esplendidas mulheres, ha arte, ha poesia, e onde ha poesia, ha sonho, ha êxtase, ha embevecimento, ha perfumadas attitudes de crédulo e romântico optimismo. Dedicamos a nossa revista à mulher espírito-santense.A mulher ainda é, na vida, a mais ardente protectora da arte e a mais requintada amiga do sonho (VIDA CAPICHABA apud 80 ANOS DE..., 2003, p. 7).

Tudo o que o ideário moderno compreendia era passível de constar como foco de debate ou crítica na revista. A multiplicidade que esse formato alojava abrangia todas as esferas afetadas pelo sonho de ser moderno e civilizado que atingia a elite do País afeitos à nova expressão urbana (regenerada e higienizada) e às diversas tecnologias que incrementavam o cenário em movimento (RANGEL, 2011). De fato, a Vida Capichaba, com seu hibridismo temático e o forte investimento gráfico e de imagens, veiculou sensibilidades, desejos e comportamentos da vida social de Vitória. Sua presença nas casas da elite social constituiu fonte de divulgação e reprodução dos valores urbanos. Analisar, portanto, a revista permite conhecer as imagens de mulher que foram projetadas em suas páginas durante as décadas de 1920 e 1930. Assim, esse texto ressalta uma das temáticas mais abordadas pela revista: a beleza. Trata-se, a partir de então, de uma mulher que tem o dever de ser bela e que precisa educar e dominar o seu corpo para a aquisição da beleza. Não obstante, passa a ser mais vista e valorizada a partir da ideia de "belo sexo" direcionada 
ao feminino. No primeiro momento mostramos como a revista deu destaque ao rosto feminino. A beleza e os cuidados com a face se mostraram primordiais, desenhos de rosto ou imagens de mulheres que compunham a sociedade capixaba obtiveram destaque ao longo de suas edições. Na sequência, apontamos como a beleza moderna se expande para todo o corpo; um corpo mais a mostra, mais visível na cidade precisa ser mais cuidado e a revista tratou de observar e dar conselhos às mulheres do Estado, "ajudando-as" na tarefa de se fazerem belas. Por fim, apontamos nossas conclusões.

\section{Rostos desenhados}

A valorização e o incentivo ao culto da beleza foram uma das temáticas mais

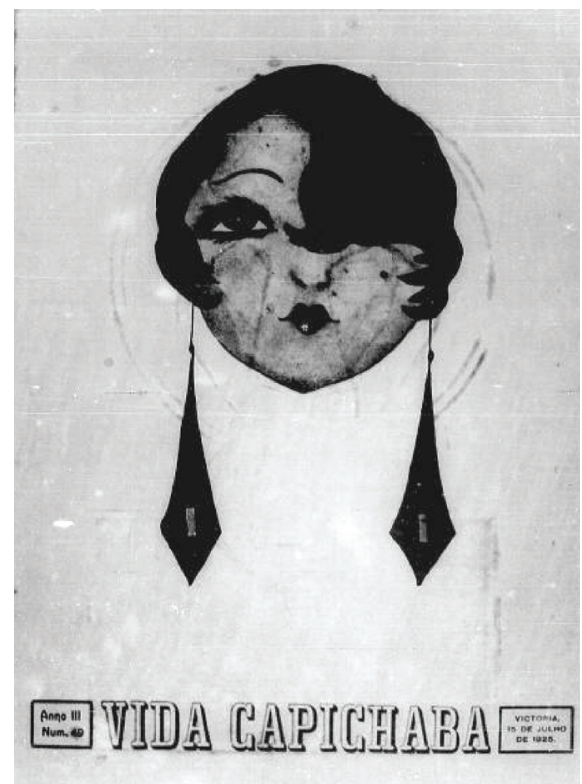

Figura 1 - Cabelos curtíssimos Fonte: Vida Capichaba, 15 de jul. 1925. abordadas na Vida Capichaba. Os rostos do "belo sexo" compuseram fartamente as folhas do periódico. As décadas de 1920 e 1930 carregaram consigo traços finos e marcantes, seja na arte, seja na moda ou no conjunto do que compunha a beleza. Nos desenhos de mulheres apresentados pela revista ou pelas fotografias de mulheres reais, majoritariamente habitantes da Capital Vitória, os rostos desenhados eram de beldades absolutamente modernas. As formas, o olhar afetado, artificial e pretensioso são as marcas dessas faces centralizadas na revista. As bocas pequenas e bem desenhadas marcam seu lugar, especialmente por estarem muito pintadas. Afinal, a criação do batom, em 1925, marcou compulsiva e ansiosamente o rosto feminino (DEL PRIORE, 2000). Este se destaca, em especial, pelos cabelos cortados à la garçonne.

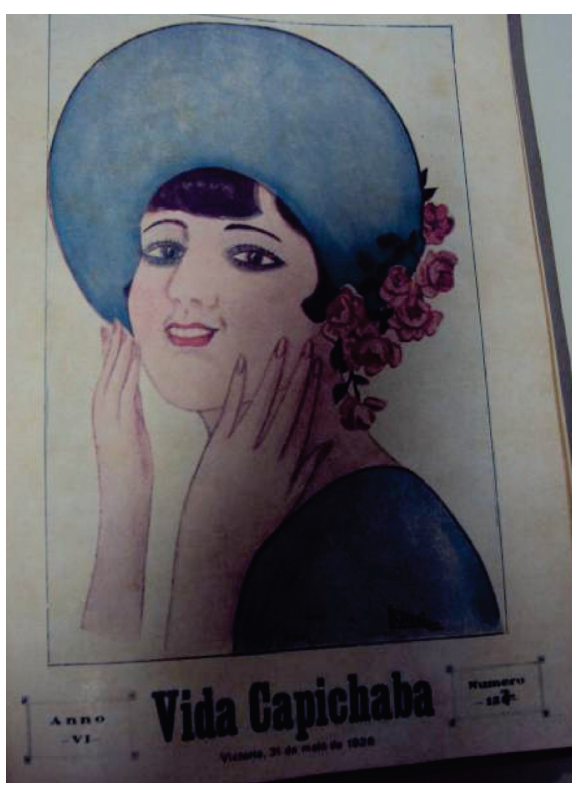

Figura 2 - Novo cabelo, novo chapéu Fonte: Vida Capichaba, 31 de maio 1928. 


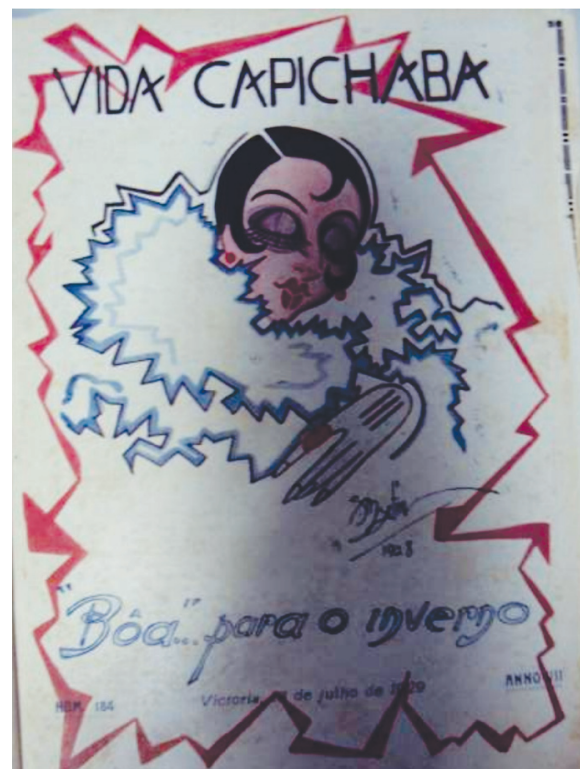

Figura 3 - Capa de julho de 1929 Fonte: Vida Capichaba, 16 de jul. 1929.

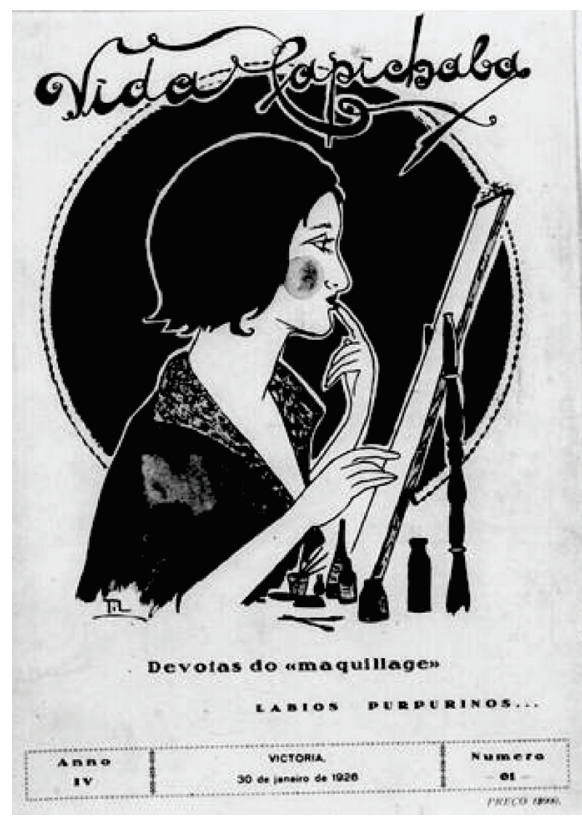

Figura 4 - Devotas da maquiagem Fonte: Vida Capichaba, 30 de jan. 1926.
O cabelo sempre teve destaque na construção do feminino. Ele é considerado símbolo da mulher. No fio do tempo, as vastas cabeleiras aproximaram a mulher $\mathrm{da}$ natureza e da animalidade. "Os cabelos são a mulher, a carne, a feminilidade, a tentação, a sedução, o pecado" (PERROT, 2008, p. 55). Eles foram símbolo da inferioridade feminina. As longas madeixas a serem cuidadas, cobertas com véus ou enfeitadas e penteadas fazem parte da história do corpo. Como assinala Perrot (2008), a imagem cristã coloca, por sua vez, uma ambiguidade no que representam. Foi com os seus cabelos que Maria Madalena enxugou os pés de Jesus Cristo. As mulheres se aproximam da imagem dos anjos por seus cabelos, pois as figuras deles sempre têm cabelos destacados. Os cabelos carregam conjuntamente a contradição da sacralização e o artifício da sedução.

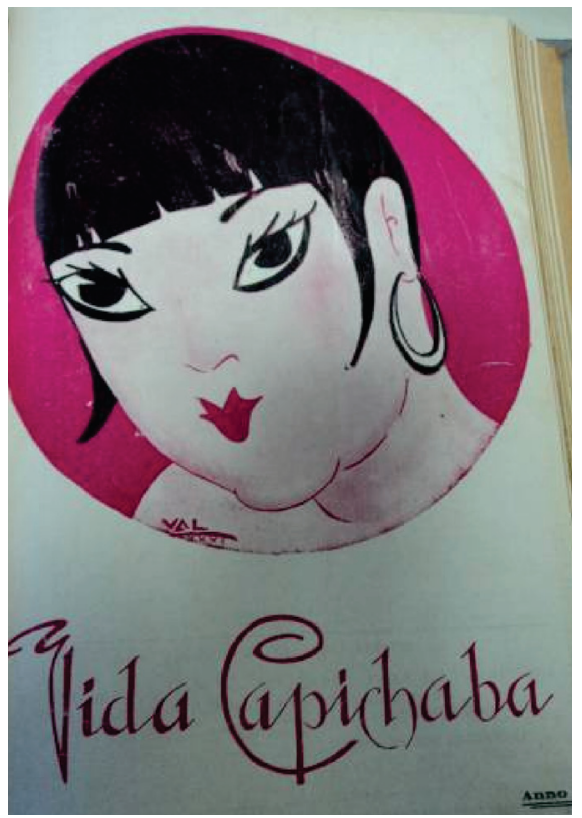

Figura 5 - Capa de março de 1927 Fonte: Vida Capichaba, 31 de mar. 1927. 
Por sua vez, é preciso marcar a importância desse novo corte de cabelo, tão curto, inovador e distinto do historicamente construído. Com a chegada dos anos 1920, o corte de cabelo tão atrevido, inovador e irreverente, como la garçonne, significou uma nova mulher, uma nova feminilidade. A liberação e desprendimento do uso de véu e, posteriormente, de pesados chapéus arrematam a atenção dada aos cabelos. A praticidade desse corte simplificou os cuidados com as madeixas. A leveza ocupou o lugar do pesado e do embaraçador.

Segundo Vigarello (2006), o romance de Victor Margueritte, intutulado La Garçonne traz na sua obra uma denúncia às restrições vividas pelas moças. O choque foi tão g rande que essa expressão se transformou em palavra comum, mas com impacto de rupturas, com influência no físico das mulheres e com caráter revolucionário. Por um lado, os cabelos curtos causam reboliço, estranhamento e criam uma estranha e inovadora aparência "unissex"; por outro, colocam definitivamente o rosto mais à mostra, como podemos observar nas imagens/ desenhos da Vida Capichaba.

O rosto tem, tradicionalmente, lugar privilegiado no conjunto da beleza feminina e se mostra na harmonia da estética física com grande profundidade (VIGARELLO, 2006). O rosto toma um lugar importante nos cuidados com o corpo, ocasião para a emergência de estratégias para torná-lo cada vez mais belo. O reconhecimento da pele como órgão, a disponibilização dos cosméticos, a ampliação de seus usos, propiciado pelo desenvolvimento de novos produtos e da divulgação feita pela imprensa, vão colocando gradativamente os cuidados com a pele como algo possível, preciso e pioneiramente prazeroso (SOARES, 2010). As emoções, os traços e os tons que compõem um modelo de rosto trazem consigo o estado determinado da beleza e, também, o que deve ser ignorado. As imagens de mulheres da revista Vida Capichaba, nas décadas de 1920 e 1930, concretizam uma fisionomia à moda, demonstram uma aparência atual, um modo de embelezamento pelo qual as mulheres devem se guiar. No Brasil, essa forma de ser bela - rostos traçados e idealizados - revela também o desejo de ser moderno e civilizado, ideal encarnado pela elite do País (SANT'ANNA, 1995). A maquiagem e a pele branca em perfeito estado quase se fundem. Algumas das imagens se fazem com um fundo branco, em que o rosto belo e sua tez branca estão em harmonia. Outras apresentam cores paralelas, compostas por traços ou sombras, os quais, unidos aos desenhos das sobrancelhas, finas e pretas, mostram uma beleza inalterável e artificial (VIGARELLO, 2006). Cabelos lisos e brilhantes, traços finos e delicados, rostos lisos emoldurados por cabelos curtos e faces habilmente maquiadas são o retrato da beleza desenhada e apresentada na revista. 


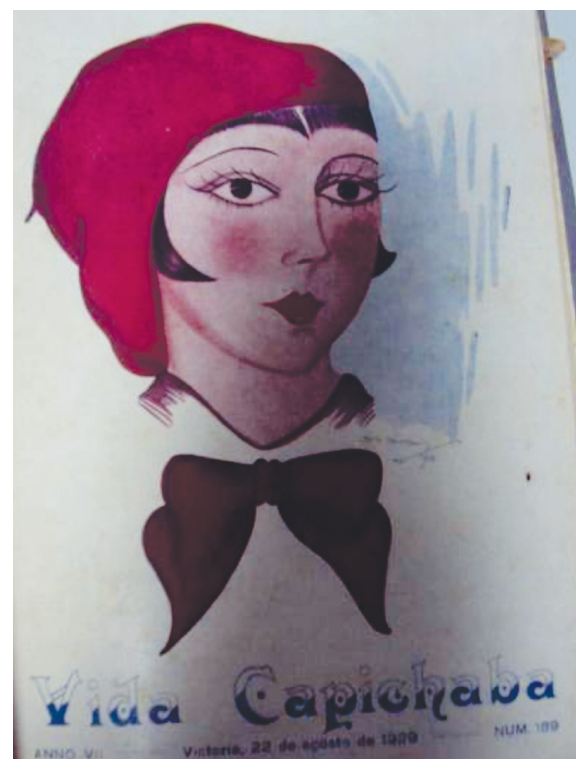

Figura 6 - Rouge e batom 1 Fonte: Vida Capichaba, 22 de ago. 1929.

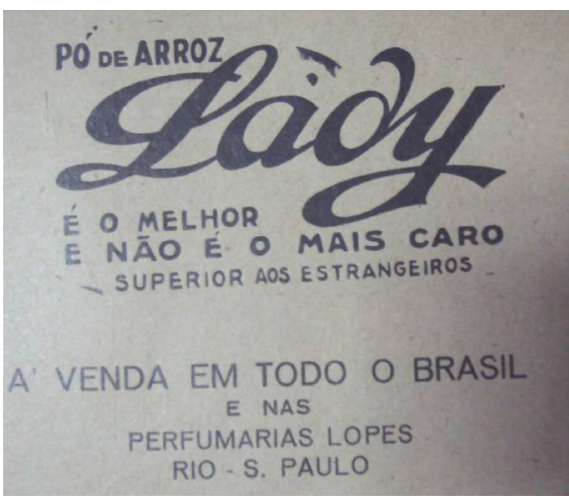

Figura 8 - Para maquiar-se Fonte: Vida Capichaba, 2 de jan. 1930.

A maquiagem está absolutamente em evidência nessas imagens, como um recurso em desenvolvimento que estava se tornando um instrumento cotidiano, parceiro do "belo sexo". A maquiagem constitui

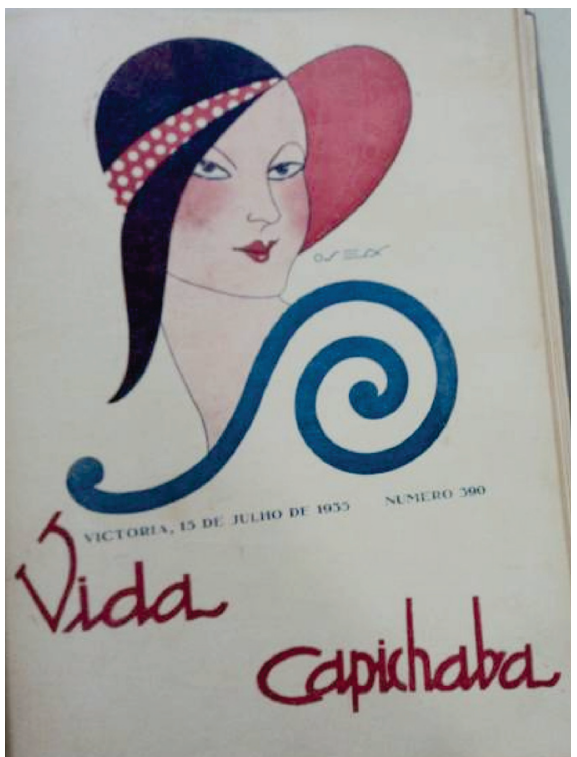

Figura 7 - Rouge e batom 2 Fonte: Vida Capichaba, 15 de jul. 1935.

requisito fundamental de beleza. Cosméticos, pós, sombras, máscaras para cílios, delineadores, crayon e batons, uma série de produtos já disponíveis não mais para correção dos traços, pois "[...] o rosto, sem ela, mostra-se definitivamente 'malcuidado', 'não limpo', 'não acabado" (VIGARELLO, 2006, p. 79). Processo primeiro e último do conjunto de possibilidades e obrigatoriedades que compõe o ser bela, a maquiagem se torna expressão da mulher e quase uma questão de higiene (ECO, 2004). A valorização da beleza pela revista indica que ser bela deixava de ser uma possibilidade e passava a ser um dever. Como apontam Albino e Vaz (2005), a referência ao "belo sexo" leva consigo não apenas uma adjetivação, mas, também, o imperativo de fazer-se bela. As imagens apresentadas em seu conjunto colocam certo "dever ser" feminino, que 
passa fundamentalmente pela constituição de um dever ser bela, no qual as imagens mostram o que se deve buscar atingir.

A vitória da beleza e do rosto belo está na exterioridade da pele; é para a cútis o primeiro cuidado, pois é para ela que se lança o primeiro olhar. A manutenção de um rosto jovem, limpo e com uma pele saudável foi regulada pelos produtos de beleza e higiene que compõem o que Vigarello (2006) nomeou de "renovação estética física do começo do século XX". A arte de se embelezar se desenvolveu e, assim, ampliou o olhar destinado à beleza. Atingir a beleza em todo seu conjunto ganhou conotação de revitalização e de construção. A beleza é como um grande projeto, que passa pelos cuidados com o rosto, o corpo, pela adesão aos processos e técnicas em evidência, pelo uso de produtos cosméticos e de higiene, que passam, segundo Vigarello (2006), a serem chamados de "produtos de beleza".

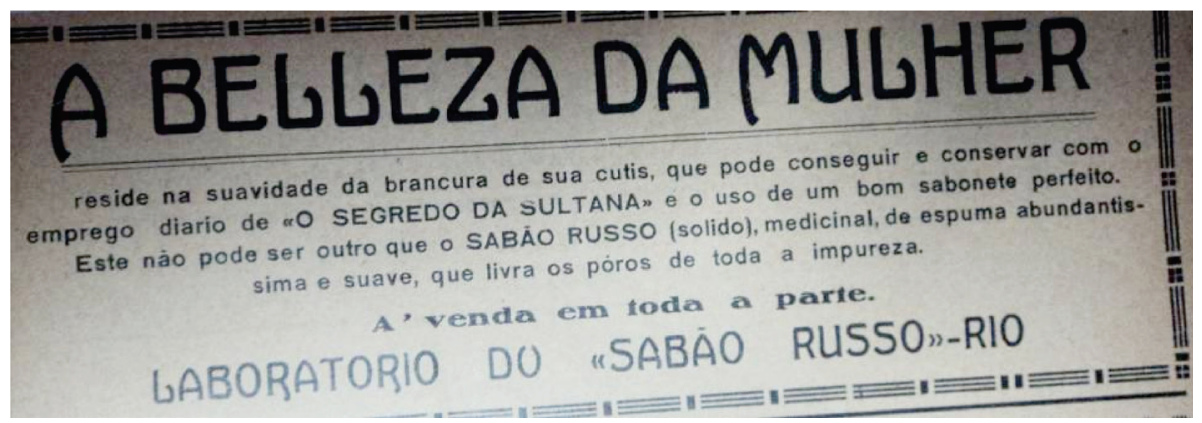

Figura 9 - A beleza da mulher Fonte: Vida Capichaba, 19 de jan. 1928.

Os desenhos de mulheres maquiadas e cabelos curtos são expressões do que se deve buscar; são as imagens que as capixabas deveriam procurar para si mesmas. A revista se responsabiliza em mostrar, por meio dos recursos visuais, o que é considerado bonito e apreciável. O ponto é que essas imagens tiveram espaço importante na revista e sua função não era "completar" o periódico, colori-lo ou torná-lo simplesmente mais interessante; essas imagens buscaram ser uma linguagem que transmitiria com facilidade as informações necessárias à leitora, educando-a e seduzindo-a em favor dos novos modos de ser. Segundo Albino e Vaz (2005), as imagens de mulheres na imprensa das primeiras décadas do século $\mathrm{XX}$ as apresentam sorrindo, ou com um olhar distante; são musas que devem ser admiradas.

Rostos levemente inclinados, moças abandonadas a seus devaneios, as belas se entregam, ao mesmo tempo, ao olhar do espectador. De certo modo, as moças se fazem vistas e se mostram antenadas aos novos hábitos. Os desenhos de mulheres com belos semblantes são conselhos que lhes propõem o modelo e as regras da beleza. As fotos dos rostos das capixabas obedecem ao imperativo das ilustrações que as mulheres carregam consigo. Os desenhos femininos estampados na revista serviram 
como exemplos de beleza que as moças capixabas deveriam buscar. Para Cunha (2011), os veículos de comunicação, atentos à nova sensibilidade urbana, viram nas fotografias um meio propício para educar a sociedade. A beleza e os rostos femininos constituíam temas. Ao difundir imagens de mulheres das camadas elitizadas do Estado portando belos trajes e uma aparência "à moda", a revista divulgava o modelo de beleza e o modelo de mulher apreciável a partir da moças-exemplo da sociedade local. Tal divulgação as colocava no pedestal da beleza e dos modos louváveis da cidade como manequins, aos quais os olhares se destinavam. As imagens dessas mulheres são como objetos decorativos e ornamentos (VIGARELLO, 2006) que circulam pelos espaços da urbe.

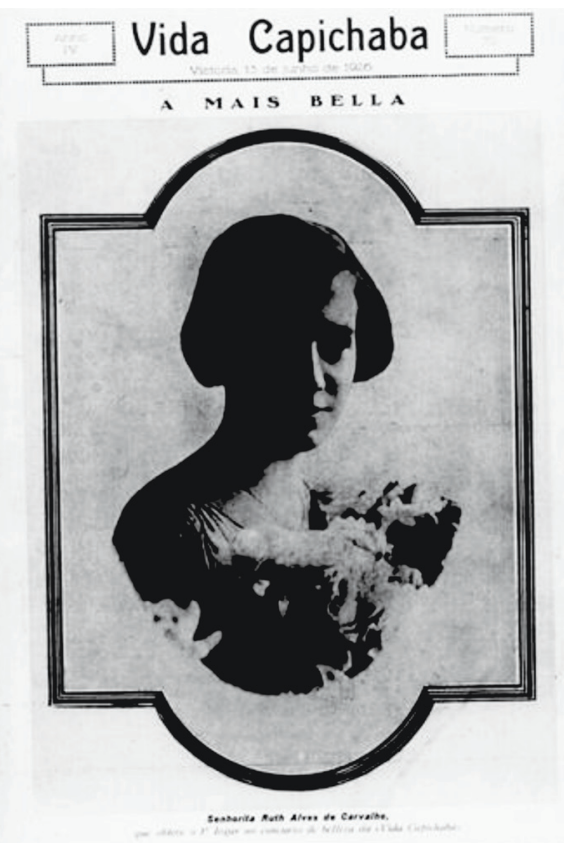

Figura 10 - A mais bela Fonte: Vida Capichaba, 15 de jun, 1926.

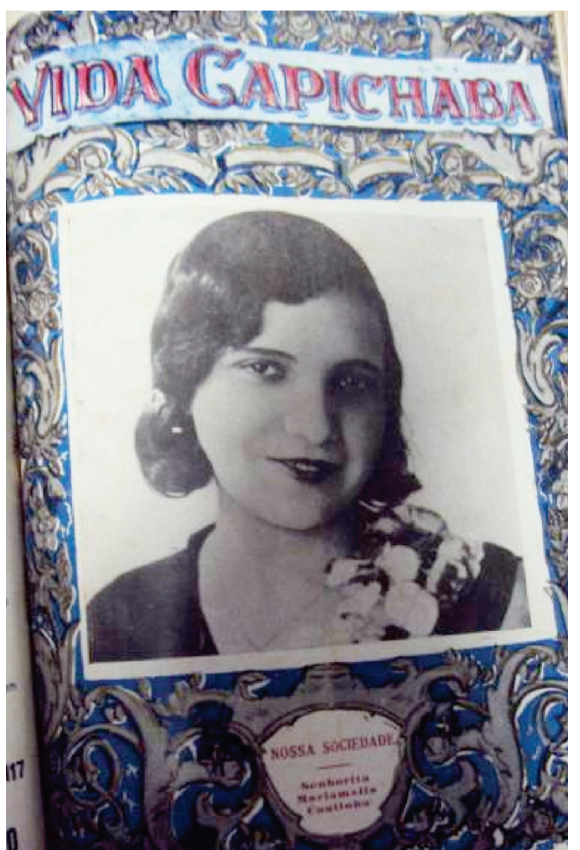

Figura 11 - Nossa sociedade Fonte: Vida Capichaba, s/d, 1929. 


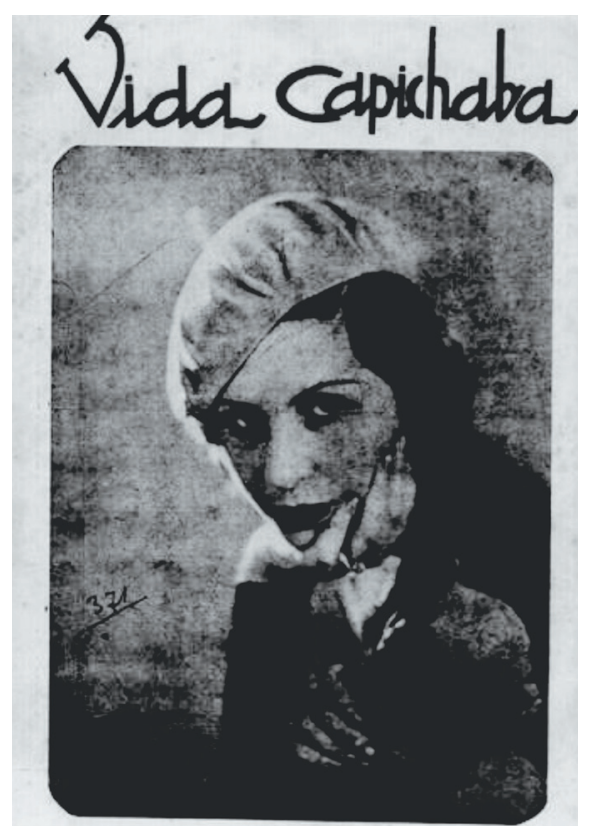

Figura 12 - Capa da Revista Fonte: Vida Capichaba, s/d, 1934.

As imagens de mulheres desenhadas ou de mulheres reais fotografadas foram reproduzidas por todo o ciclo da Vida Capichaba. As capas são uma confirmação da importância que o periódico deu à imagem feminina da Capital. A capa ilustra e anuncia o que é a revista; as fotografias dessas mulheres em destaque absoluto denotam um determinado espaço no seio da cidade, afirmando a posição diferenciada que já ocupam na sociedade.

O ato fotográfico foi se construindo, de modo seletivo, dignificando e privilegiando, um determinado grupo de indivíduos. Ao retratar as "senhorinhas do fino ornamento vitoriense" (VIDA CAPICHABA, 1926, s/p) o periódico delimitava os grupos para os quais a revista pertencia e as pessoas que tinham o direito e a honra de serem

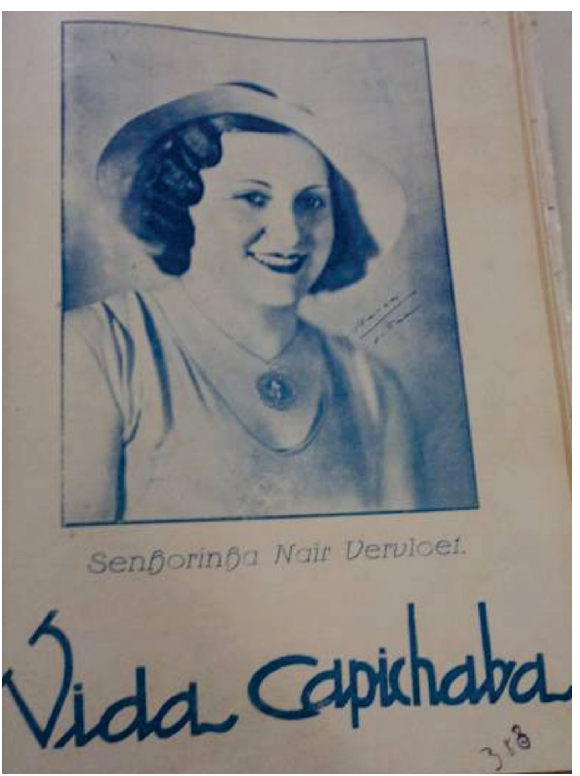

Figura 13 - Senhorinha Nair Vervicet Fonte: Vida Capichaba, s/d, 1935.

registradas e, sobretudo, de compor a revista. Essas imagens vão, assim, instituindo uma forma de regular o espaço urbano (MAUAD, 2005) e o corpo feminino.

Mulheres bonitas, em poses adequadamente pensadas, com sorrisos que demonstravam familiaridade com a tecnologia da câmera, evidenciam uma mulher conectada com os sentidos de desenvolvimento e crescimento que permeavam a Capital do Espírito Santo. Essa presença dos corpos femininos na capa da revista também revela uma maior liberdade concedida aos desejos das mulheres (VIGARELLO, 2006). Desejos de ver, de serem vistas e de participar dos novos espaços e novas tecnologias urbanas. A aparência estava à mostra.

A beleza compunha esse conjunto: aparência física, prestígio e reconhecimento 
da sociedade espíritossantense. Estampar as folhas da revista mais importante do Estado pode ser interpretado como um grau de escape, um modo de liberação. É um modo de tomada de posse do "eu", defendido por Lipovetsky (1997), visto que as mulheres ali registradas se fizeram ver. Tiveram suas imagens publicamente visíveis, não mais restritas ao olhar do marido e dos familiares. Por outro lado, a norma existe. Afinal, ser símbolo de beleza da sociedade vitoriense pressupunha trabalho, cuidado individual e a adesão às novas normas sociais a elas destinadas. As imagens fotográficas funcionavam como um dispositivo pedagógico de um constituir-se feminino. A beleza deveria ser construída e mantida, pois se tornara responsabilidade individual. Há de se lembrar que, nas primeiras décadas do século XX, havia no Brasil uma moral ligada a regras católicas. A Igreja via negativamente o desejo de embelezar-se e a exposição da imagem poderia manchar a honra das moças de família, por poderem ser interpretadas como desejos duvidosos e profanos (SANT'ANNA, 1995); já as imagens da revista Vida Capichaba e a própria revista não estavam tão preocupadas com isso. Talvez, por entender que os processos de educação moral e de valores comportamentais destinados ao feminino já estivessem firmemente consolidados, divulgados e apreendidos, o periódico estava mais atento e preocupado em vestir a máscara moderna, assumindo a ideia de que a beleza era fruto do trabalho individual e cotidiano da mulher sobre si e que tal valor não a impediria de ser considerada "boa moça". As imagens relacionadas à beleza não apagam a imagem de uma mulher que é uma boa dona de casa e que segue os valores apreciados pelo próprio periódico.

\section{Os corpos femininos estampados na Vida Capichaba}

Segundo Del Priore (2000), data das primeiras décadas do século XX o advento da beleza jovem como modelo. Até o século XIX, a referência era a figura da mulher pesada e vestida de negro, gorda, mole, maternal e caseira, ou a menina do tipo franzino, com aparência frágil (FREY$R E$, 1964). Com o século $X X$, essa imagem é banida, pois o envelhecer começa a ser associado a perda de prestígio na vida pública. Velhice e gordura se associam. Saúde, prazer e beleza passam a se referir a corpos jovens e magros. O elegante, fino e belo é o corpo magro. O corpo gordo torna esse critério determinante da definição de feiúra. Com o século $\mathrm{XX}$, portanto, criaram-se as condições para o sentimento lipofóbico e a ideia de que o corpo pesado se opunha aos novos tempos, leves, alegres e excitantes (ANDRADE, 2003).

Os desenhos dos corpos femininos que dominam o periódico nas décadas de 1920 e 1930 são ousados e magros, demonstrando movimento e liberdade condizentes com os valores urbanos e cosmopolitas que emergem a partir dos anos 1920 (SEVCENKO, 1992). 


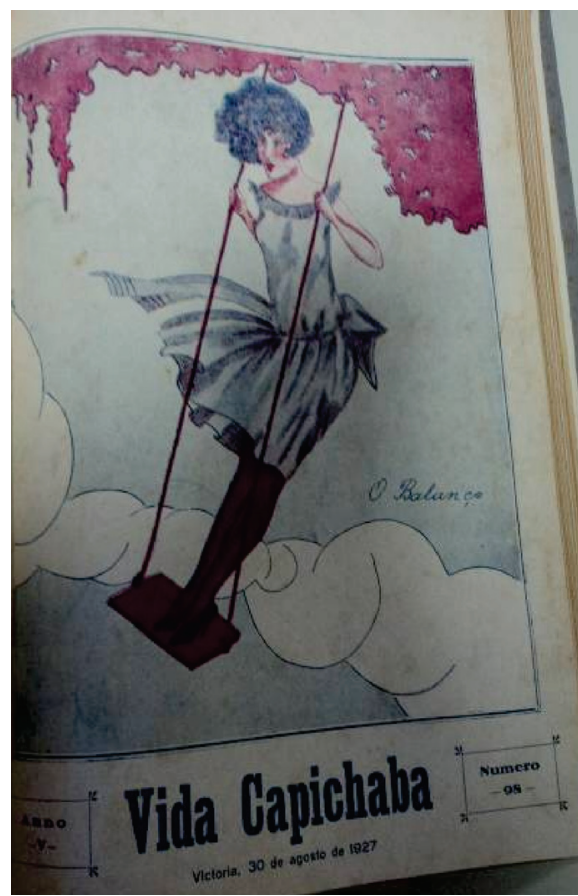

Figura 14 - Mulher em movimento Fonte: Vida Capichaba, 30 ago. 1927.

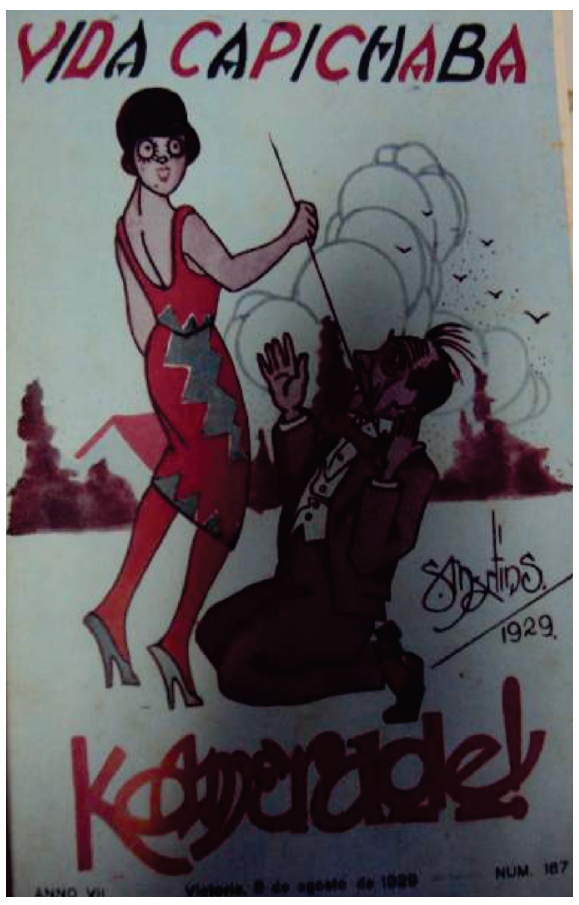

Figura 15 - Corpo atrevido Fonte: Vida Capichaba, 8 set. 1929.

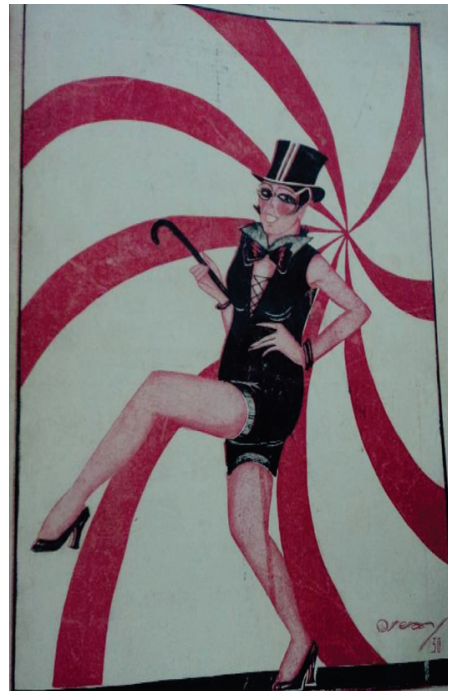

Figura 16 - Desenho descontraído Fonte: Vida Capichaba, 16 de maio de 1931. 
Lipovetsky (1997) acredita que as novas imagens atreladas ao feminino não podem ser vistas apenas como alienação da mulher e submissão de gênero, pois o atributo da beleza, o destaque do corpo feminino e a referência à sua identidade conferem riqueza simbólica. Afinal, concretizam uma valorização inédita do ser mulher, visto que elas são elogiadas e apresentadas de forma positiva. Há uma notoriedade social a partir da valorização da beleza.

Sem dúvida, o modelo apreciado e desejado lhes dá o entendimento de poderem dominar o corpo. A busca por transformações corporais e a necessidade que vai se instituindo de adequar a aparência se estabelecem como um exercício constante. A atenção dedicada ao corpo, a preocupação em se movimentar, em se tornar mais flexível e dinâmica, proporcionaram também novas possibilidades de sentir e vivenciar o próprio corpo. Essas práticas inventam uma nova arte de provar a vontade íntima (VIGARELLO, 2006). A valorização corporal difunde uma compreensão mais afinada de si mesma. Ao mesmo tempo, é uma atenção e um maior conhecimento das sensações e atividades corporais que propiciam novos desejos, novas percepções do corpo até então desconhecidas e colocam, conjuntamente, uma melhor possibilidade de o controlar. Conhecer as sensações, pensar nas possibilidades que o corpo permite, imaginar os modos plausíveis para atingir uma melhor forma física, torna a mulher mais dona de si e ao mesmo tempo a direciona para um controle do seu corpo.

Segundo Lipovestky (1997), o jogo se torna o da culpabilidade. As novas relações consigo mesmo, propiciadas pela compreensão de saúde e beleza, pela influência das estrelas de cinema, dos esportes e pelo crescimento da imprensa deslocam a posição de "autoridade". As imagens trabalham com conselhos e não com ordens explícitas. Os conselhos distinguem e separam as que "têm vontade" das que "não têm vontade" e claramente as que não têm vontade são rechaçadas, afastadas e tidas como desleixadas. Ao pressupor uma participação ativa das moças, a responsabilidade sobre seu estado físico e aparência passa a ser atribuída a elas.

Para Lipovetsky (1997), esse novo corpo, esquadrinhado pela medicina estética, tornou-se o grande objeto de consumo. A liberdade corporal apresentada pelas "estrelas de cinema" desde os anos 1930, reforçada pelo cinema do pós-guerra, iniciou as marcações corporais de hoje. Maior sensualidade, gestos desenvoltos e até a confusão de fantasias que elas geravam em telespectadoras e telespectadores demarcaram o lugar da erotização. As imagens de uma beleza mais provocante, comportamentos mais liberados que enfrentavam convenções moralistas colocaram as partes do corpo mais à mostra e com uma importância marcante que criava uma visão nova do desejo feminino e de sua liberdade (VIGARELLO, 2006). O cinema influenciava não só os padrões de beleza e o vestuário das mulheres, mas, também, o imaginário sexual feminino. Os beijos e as cenas de toque entre homens e mulheres, vistos em filmes, passavam a povoar a cabeça das jovens, que tinham na revista a possibilidade de "gravar" as cenas dos filmes e/ou as imagens das jovens, belas e livres atrizes. "As formosuras que se expunham na tela puderam deixar no agitado ambiente de adoração o exato e sugestivo reflexo de suas graças pessoais, consagrando-se como rainhas da beleza. A beleza feminina constrói-se sob a influência da beleza cinematográfica" (SANTOS, 2013, p. 19). 


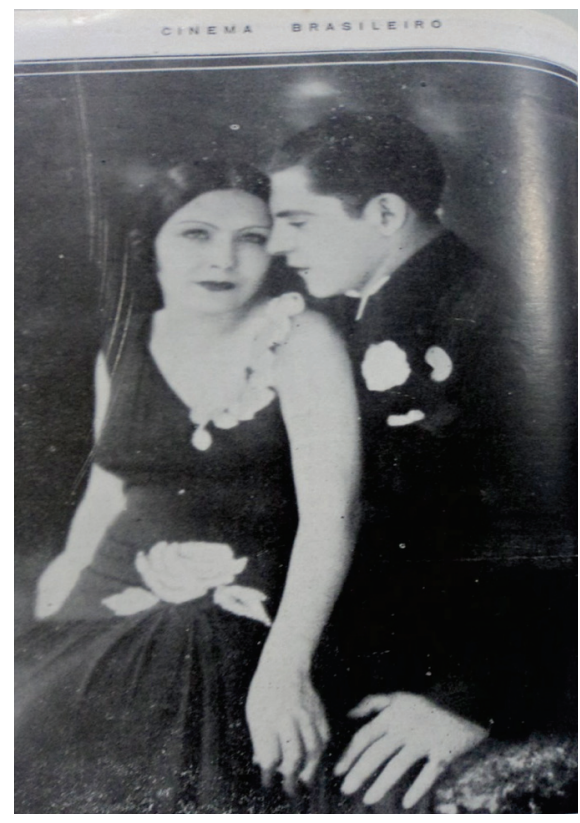

Figura 17 - Nossos astros Fonte: Vida Capichaba, 30 de jun, 1931.

\section{CONCLUSÕES}

A maquiagem do rosto, o olhar, o sorriso à mostra, a liberdade e a praticidade dos cabelos la garçonne, o advento do corpo e a exibição de mulheres reais nas páginas da revista Vida Capichaba permitem um novo modo de ser mulher. Aproximando-se da nova compreensão acerca do corpo, o ápice da ideia de "belo sexo", destinada ao feminino, criou também normas estéticas que impuseram um modelo rígido a ser seguido. O século XX rompe, por fim, com uma visão maledicente e perigosa da beleza feminina. As mulheres podiam ser belas; não era mais um dom dado ao nascer, tampouco um pecado mortal. A beleza feminina se emancipava, se liberava, aos poucos, dos pesos morais e religiosos. De

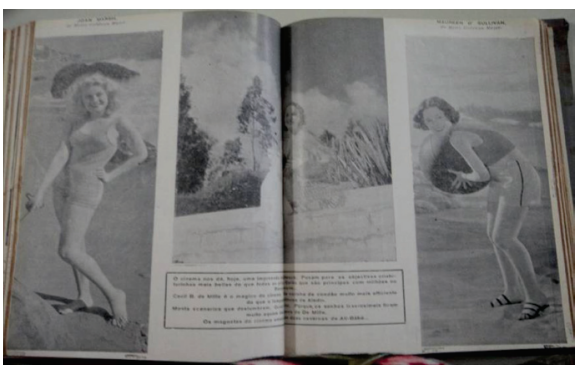

Figura 18 - "Belas criaturinhas"

Fonte: Vida Capichaba, 15 jun. 1932.

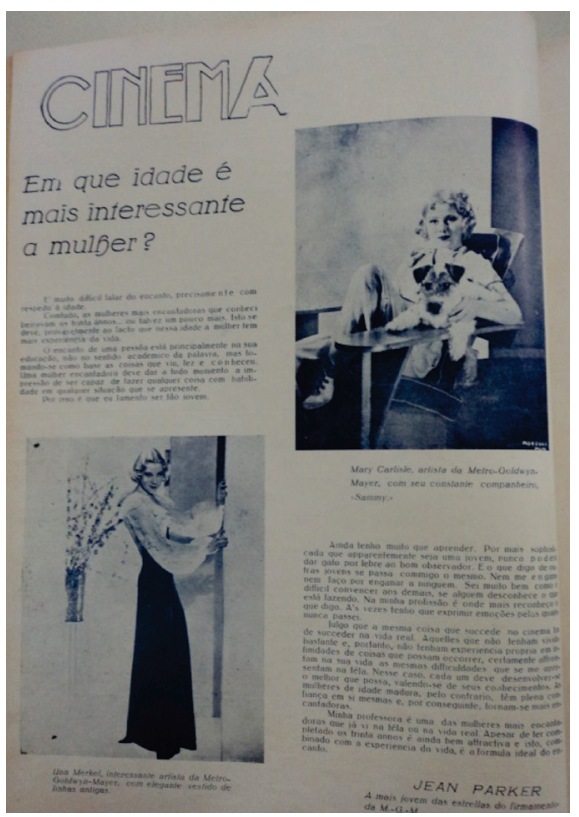

Figura 19 - Influência do cinema Fonte: Vida Capichaba, s/d, 1935.

fato, elas deviam ser belas, pois diferentes possibilidades estavam se construindo, tanto de cunho tecnológico - cosméticos, maquiagens e roupas -, como no campo dos novos valores. A pureza e a sensualidade começaram a andar juntas. A ambiguidade presente na revista diz à mulher que ela podia (e 
devia) ser bela. A mulher pôde e passou a querer a beleza. Um modo de ser mulher ia se constituindo pelas vias da beleza, uma beleza "mais acessível", mas sem deixar de ser "um dever, uma obrigação". As mulheres do Espírito Santo, às quais a revista se direcionava, em conformidade com as mulheres de outras regiões do País, experimentavam as possibilidades antagônicas oferecidas nesse período (SANT'ANNA, 1995).

O jogo de sedução e beleza estava se instituindo e é por meio do olhar que ele é inserido. Neste sentido, a Vida Capichaba mostrava como a busca pelo embelezamento poderia ser uma atividade prazerosa. A revista, além de divulgar uma série de produtos e de possibilidades de consumo, buscou educar as mulheres ao desejo de consumir e de expor determinada imagem. Ao criar um desejo de semelhança, a revista cerceava originalidades e singularidades, visto que as moças que posavam para capas ou reportagens internas tinham o mesmo corte de cabelo, o mesmo desenho de sobrancelha e o modo de posar semelhantes. Difundindo fotografias de "exemplos a serem seguidos", rompendo com as diferenças individuais. A beleza apresentada, ao mesmo tempo em que liberava e tornava mais conhecida a imagem do feminino, impunha um modelo único de beleza e estabelecia um padrão a ser alcançado.

\section{REFERÊNCIAS}

ALBINO, B. S. e VAZ, A. F. Mulher, como deves ser: um estudo sobre a educação do corpo feminino. In: Jornal Dia e Noite (1940-1941). Temas e Matizes. Cascavel: Unioeste, a. IV, n. 7, 2005.
ANDRADE, S. dos S. Saúde e beleza do corpo feminino - algumas representações no Brasil do século XX. In: Movimento, Porto Alegre, v. 9, n. 1, p. 119-143, jan./abr., 2003

CUNHA, L. B. As roupas esportivas em Revista na cidade de Belo Horizonte (1929-1950): moldes, recortes e costuras. 2011, 172 f. Dissertação (Mestrado em Educação Física) - Faculdade de Educação Física - Universidade Estadual de Campinas, Campinas, 2011.

DEL PRIORE, M. Corpo a corpo com a mulher: pequena história das transformações do corpo feminino no Brasil. São Paulo: Senac, 2000.

ECO, U. História da beleza. Rio de Janeiro: Record, 2004.

FREYRE, G. Casa-grande e senzala: formação da família brasileira sob o regime de economia patriarcal. Rio de Janeiro: Olympio, 11. ed., 1964.

LIPOVETSKY, G. A terceira mulher: permanência e revolução do feminino. São Paulo: Cia. das Letras, 1997.

MAUAD, A. M. Na mira do olhar: um exercício de análise da fotografia nas revistas ilustradas cariocas, na primeira metade do século XX. In: Anais do Museu Paulista, v. 13. n.1., jan./ jun. 2005.

MELO, V. A. Esporte, propaganda e publicidade no Rio de Janeiro da transição dos séculos XIX e XX. In: Revista Brasileira de Ciências do Esporte, v. 29, p. 126-134, 2008.

MARTINUZZO, J. A. (Org.). Impressões capixabas: 165 anos de jornalismo no Espírito Santo. Vitória: Departamento de Imprensa Oficial do Espírito Santo, 2005.

PERROT, M. Minha história das mulheres. São Paulo: Contexto, 2008. 
RANGEL, L. A. S. "Feminismo ideal e sadio": os discursos feministas nas vozes das mulheres intelectuais capixabas. 2011. 268 f. Dissertação (Mestrado em História) - Programa de Pós-Graduação em História, Universidade Federal do Espírito Santo, Vitória, 2011.

SANT'ANNA, D. B. Cuidados de Si e Embelezamento Feminino: Fragmentos para uma história do corpo no Brasil. In: Políticas do Corpo. São Paulo: Estação Liberdade, 1995.

SANTOS, C. C. História e propaganda: análise de corpos femininos em imagens publicitárias na década de 20. Rev Eletrônica História ANPUH. 2006. Acesso em: 11 nov. 2013. Disponível e m : www.anpuh.org/arquivo / download?ID_ARQUIVO=75.

SEVCENKO, N. Orfeu extático na metrópole: São Paulo, sociedade e cultura nos frementes anos 20. São Paulo: Companhia das Letras, 1992.

SOARES, C.L. As roupas nas práticas corporais e esportivas: a educação do corpo entre o conforto, a elegância e a eficiência (1920-1940). 2010. 171 f. Tese de livre docência. Universidade Estadual de Campinas, Campinas, 2010. VIGARELLO, G. História da beleza. O corpo e a arte de se embelezar, do renascimento aos dias de hoje. Rio de Janeiro: Ediouro, 2006.

80 ANOS DE VIDA CAPICHABA: edição comemorativa. Vitória: Instituto Histórico e Geográfico do Espírito Santo, abril de 2003.

\section{Imagens:}

Figura 1. , a. III, n. 49, s/p,

15 jul. 1925.

Figura 2. a. VI, n. 127, s/p,

31 maio 1928.

Figura 3. a. VII, n. 184, s/p, 16 jul. 1929

Figura 4. a. IV, n. 1, s/p, 30 jan. 1926.

Figura 5. a. V, n. 89, s/p, 31 mar. 1927.

Figura 6. a. VII, n. 189, s/p, 22 ago. 1929.

Figura 7. n. $390, s / p, 15$ de jul. 1935.

Figura 8. s/p, 2 de jan. 1930.

Figura 9. a. VI, n. 107 s/p,

19 jan. 1928.

Figura 10. a. IV, s/p, 15 jun. 1926.

Figura 11. s/p, s/d, 1929.

Figura 12. $s / p, s / d, 1934$.

Figura 13. $s / p, s / d, 1935$.

Figura 14. , a. V, n. 98, s/p, 30 ago. 1927.

Figura 15. a. VII, n. 187, s/p, 8 set. 1929.

Figura 16. a. IX, n. 276, s/p, 16 maio. 1931.

Figura 17. a. IX, n. 281, s/p, 20 jun. 1931.

Figura 18. a. X, n. 320, s/p, 15 jun. 1932.

Figura 19. s/d, s/p, 1935. 
BEAUTY AND FEMINITY: the female body in the periodical Vida Capichaba (1925 - 1939)

\begin{abstract}
This paper investigates images of the feminine present in the periodical Vida Capichaba, a magazine published biweekly in the State of Espirito Santo, Brazil, between the decades of 1920 and the 1950. Due to the periodical's publication longevity, the authors decided to focus their analytical work on the 1920s and 1930s, specifically between 1925 and 1939. Understanding that the illustrated magazine registered history in a language of images and basing that study on Mauad (2005), the authors focused their work on the analysis of images. It was revealed that the extent to which images integrated and composed the periocal equaled the texts published in it. The construct of beauty and of a slim and young body became characteristics of the new Capichaba woman [from the State of Espirito Santo], both belonging to the images that were most addressed by the journal. The search for beauty not only highlights the feminine existence, but also establishes rules of corporal behaviour.
\end{abstract}

Keywords: Feminine Body; Beauty; Periodical

BELLEZA Y FEMINILIDAD: el cuerpo femenino en las páginas de la revista Vida Capichaba (1925-1939)

\title{
RESUMEN
}

Este artículo investiga imágenes de lo feminino presentes em la revista Vida Capichaba, periódico de publicación quincenal que circuló, en el Estado de Espírito Santo, entre las décadas de 1920 y 1950 . Delante de la duración del periódico, optamos por concentrar nuestros esfuerzos analíticos en las décadas de 1920 y 1930, específicamente entre los años de 1925 y 1939. Consta, que la revista ilustrada registró la historia en lenguaje de imágenes, basándonos en Mauad (2005), hemos tomado las imágenes para analizarlas, entendiendo que estas han integrado y compuesto la revista de forma tan importante como en los textos que allí se publicaron. La construcción de la belleza y de un cuerpo delgado y joven se tornaron características de la nueva mujer capixaba, siendo esas algunas de las imágenes más abordadas por el periódico. La busca por la belleza pone la existencia femenina en destaque, pero también determina reglas de comportamiento corporal.

Palabras clave: Cuerpo Femenino; Belleza; Periódico 